\title{
TAKAKURA COMPOST MAKING TRAINING JOGLO VILLAGE, WEST JAKARTA
}

\author{
Yuni Astuti ${ }^{1}$, Tafiprios $^{1}$, Cristina Catur Widayati ${ }^{1}$ \\ ${ }^{1}$ Management Program, Economics and Business Faculty \\ Mercu Buana University \\ yuni_astuti@mercubuana.ac.id
}

\begin{abstract}
Takakura method to solve the problem of the accumulation of organic waste in the household environment, especially in the kitchen where the mother is cooking, provided that the hygiene is not smelly and not dirty, considering the kitchen where food is processed.. The purpose and objective of this activity is to provide training to housewives especially Citizens Association (Indonesian known as RW)001, 002, 003, 004, 006 and 008 in Joglo Village about making Takakura compost, so that the mother can solve the problem of household waste after cooking. Conclusion Community Service Program with the theme "Composting Waste of Household Kitchen Supporting Environmental Sanitation" is 1). Can increase the added value of mothers' skills in composting household kitchen waste with the Takakura Method, 2). Can improve the application of science and technology, by utilizing organic material microorganisms as decomposers, 3). Can improve the improvement of people's values, especially family health. The suggestion is to conduct further training on the use of organic waste from composting in preserving the environment and its marketing, 2). It is necessary to collaborate with private companies that have more organic waste such as restaurants, so that the processing of kitchen waste does not pollute the environment.
\end{abstract}

Keywords : Takakura compost, joglo village

\section{INTRODUCTION}

\section{Situaton Analysis}

Takakura's composting method is very helpful for housewives who are dizzy with household waste after cooking. By composting, Takakura kitchen can be directly cleaned because vegetable waste can be directly disposed of in a plastic or bamboo basket that we have prepared.The process of making Takakura compost is very easy, before we prepare a starter of microorganisms and make compost seeds first. Is this preparation enough to be done once, then just do composting continuously and this can be done by housewives who are busy cooking in the kitchen.

Indonesia is a tropical country, sometimes it rains continuously, sometimes it is hot, so microorganisms can breed quickly, so the composting of Takakura is very helpful for housewives who have problems with organic waste, which results in preventing bad odors, preventing seedlings, and consequently the household environment we are clean and the occupants are healthy.Composting is very necessary because household organic waste can reach $50 \%$ of the overall waste, so by composting housewives have reduced $50 \%$ of the waste disposed of. It would be nice if all households do this composting, billions of funds will be saved by each city to finance transportation, management of storage bins and environmental impacts due to mounting garbage can be overcome.

The purpose of this community service activity is to empower target communities to have the knowledge of the importance of keeping the environment healthy free from the smell of organic waste by making Takakura compost that does not stink as for what will be achieved in this exercise are:1) Motivate residents in Joglo village to be active in community activities, 2) Increase the sense of community among residents for each other, 3) Growing interest in developing the ability to love the environment, 4) Make a sideline if there are other citizens who require pesticide-free organic fertilizer, 5) Fill free time, especially housewives to make organic compost, 6) Eliminating boredom in taking care of the household, 7) Increasing knowledge about the importance of utilizing free time with beneficial and beneficial activities, 8) Increasing participants' skills in making Takakura compost. 
The shape of this activity begins with the opening of preliminary training lecture by introducing PPM team, the welcome of the Joglo headman, delivery of material information about the importance of composting household organic waste and then practice how to make compost Takakura. This activity is in collaboration with Joglo Village, Kembangan District, West Jakarta, with 80 participants of housewives.

Participants in the training program were residents of Joglo Village, Kembangan District, West Jakarta, consisting of: 1) Residents of Citizens Association (Indonesian known as RW)001,002,003, 004, 006 and 008 Joglo Village, 2) PKK (is Mother's Community/ for future use PKK) GroupCitizens Association (Indonesian known as RW)001, 002, 003, 004, 006 and 008 Joglo Village, 3) Youth Organization Citizens Association (Indonesian known as RW)001, 002, 003, 004, 006 and 008 Joglo Village.

\section{Problem Formulation}

Based on the situation analysis above, the following problem formulation can be made: 1) How to make people aware of the importance of making Takakura compost in improving cleanliness in the family environment, 2) How to prepare the community to carry out the movement of composting in their families. To solve this problem, Mercu Buana University team conducted counseling and training on the importance of making Takakura compost in their families.

\section{Solutions and Targets}

The solution to solving environmental problems that are less convenient due to household waste after cooking is the active role of the community in each housewife to diligently collect dry organic waste in a container which will later be processed into Takakura compost, which is coordinated by Joglo Village. Our Mercu Buana University Team provides solutions by: 1) Provide insight into the importance of making Takakura compost from household kitchen waste, 2) Providing training on how to make Takakura compost, 3) Evaluate Takakura compost after one month of manufacture. This activity is expected to provide benefits to the health of household residents, including: a). Add knowledge about composting, b). Solve environmental problems due to household waste, c). Increase togetherness among participants. The output target that will be achieved in making Takakura compost is after training in theory and practice, the participants are expected to have knowledge about making Takakura organic compost that can solve the problem of organic waste after cooking. Besides that, you can get additional income by marketing Takakura organic compost to other residents or the surrounding community. The Target Plan can be seen in Table 1.

Table 1. The Target Plan

\begin{tabular}{|c|l|c|}
\hline No. & \multicolumn{1}{|c|}{ Type } & $\begin{array}{c}\text { Achievement } \\
\text { Indicator }\end{array}$ \\
\hline 1. & Scientific publication in ISSN journal / proceedings & Yes \\
\hline 2. & Publications on the mass media & Yes \\
\hline 3. & Increasing competitiveness & Yes \\
\hline 4. & Improving the Application of Science and Technology & Yes \\
\hline 5. & Improvement of community values & Yes \\
\hline
\end{tabular}

\section{IMPLEMENTATION METHOD}

\section{Troubleshooting Framework}

The main problem starts from the accumulation of organic waste from households every day, especially in Joglo Village, Kembangan, West Jakarta. This is due to the lack of knowledge of the target community about the importance of processing waste that starts from the household kitchen into hygienic, odorless and unclean compost.

The solution to the problem of accumulating organic waste starts from composting household kitchen waste with the Takakura Home Composting Method, so that it is expected that there will be no accumulation of organic waste in the city of Jakarta and the impact of environmental sanitation in the 
city of Jakarta is not polluted by accumulated garbage, the city of Jakarta becomes clean, beautiful and healthy for its citizens.

\section{Realization of Problem Solving}

Based on the problems faced by the target community, it is necessary to do the following problem solving steps: 1) Motivate the participants, so that they are aware that a waste-free environment is a shared responsibility, 2) Counseling to the target community to find out the importance and benefits of making Takakura compost starting from household kitchen waste, 3) Training of target communities on how to make Takakura compost, which is hygienic, clean and not rotten.

\section{Target Audience}

In accordance with the purpose of community service, the target communities who attended counseling and training were 80 people from Citizens Association (Indonesian known as RW) 01, 02, 03, 04, 06 and 08 Joglo Village, West Jakarta, consisting of PKK mothers, youth organizations and housewives .

\section{METHOD}

The methods used in this community service are: a) Counseling about the importance of making Takakura compost starting from household kitchen waste and how to make it, b) The division of groups based on Citizens Association (Indonesian known as RW), there are 6 Citizens Association (Indonesian known as RW) means there are 6 groups, c) Distribution of tools for making compost such as plastic baskets, stater, organic waste, d) Demonstration and training on making Takakura organic compost, e) Questions and answers, interaction between participants and instructors / trainers which includes how to create, constraints and benefits, e) Evaluation, by means of extension workers come to the target community after one month to see the results of composting.

\section{Takakura Compost Making Method}

The process of making Takakura compost is very easy, initially preparing starter microorganisms and making compost seeds, this step is done only once. Then do composting continuously. Broadly speaking, the steps for composting are as follows: a). Prepare starter microorganisms, b). Making Takakura compost seeds, c). Prepare the Takakura basket, d). Composting process

\section{RESULTS AND DISCUSSION}

\section{Results}

Community service activities on composting making Takakura household kitchen waste is held on Friday 04 May 2018, 09.00 to 12.00 at RPTRA FIREFIGHTERS, Joglo viage, West Jakarta. After 1 month evaluation I was held on Monday, June 4 and evaluation II of the following month on Wednesday, July 4, 2018, to see the results of composting carried out by the mothers of each Citizens Association (Indonesian known as RW) in Joglo village.

\section{Activity Materials and Equipment}

The counseling and training materials are distributed to the target audience / community consisting of PKK mothers and housewives, which consists of theoretical material and practical material. The material was explained interactively using LCD tools and discussion, question and answer between the trainer and the participants / target communities. The practice is carried out with a demonstration tool, in which the mothers of representatives from each Citizens Association (Indonesian known as RW) each get the tools and materials for the composting process. Direct practice training by demonstrating how to make a starter of microorganisms, making Takakura seeds, preparing the Takakura basket and the composting process from entering household kitchen waste materials to giving the starter microorganisms to show the results of composting.

Composting equipment in the form of plastic baskets that have been modified for the composting process (Takakura basket), 1 jar containing a starter of microorganisms, 1 jar containing 
Takakura compost seeds, which are distributed to 6 Citizens Association's (Indonesian known as RW), namely Citizens Association (Indonesian known as RW) 01, 02, 03, 04, 06 and 08 Joglo Village West Jakarta, consisting of women from PKK, Youth organization and housewives. It is expected that from 6 Citizens Association's (Indonesian known as RW) in Joglo village can develop to other Citizens Association's (Indonesian known as RW) and the surrounding community.

\section{Activity Evaluation}

Based on the attendance list, it was known that the participants at the opening until the completion of the training amounted to 80 participants consisting of women from PKK, Youth organization and housewives and attended by the ladies of Joglo Walman Debataraja Head of Village, SKM, MSi, the doctor of Puskesmas, Kasi Kesejahteraan Rakyat (Ken Marheni, SH, MA) and several mother-father employees of Joglo village, also present Trisakti University lecturers compost experts (Ir. Fennani Arpan), MBU lecturers Trival Apriadi, SE, MM and MBU Management students. All participants were interested and tried to try after arriving home, especially the mother of the village chief, Walman Debataraja, so excited that the village head did not want to miss carrying a set of composting tools for home. This activity was quite successful because no training left from the beginning to the end until the end and many questions were asked to the trainer. The following are photos of training activities for household kitchen waste composting that can support environmental sanitation at RPTRA FIREFIGHTERS kelurahan Joglo West Jakarta.

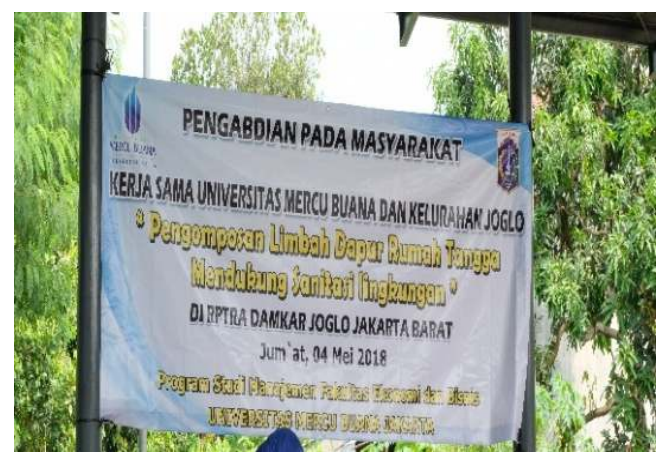

Figure 1. PPM UMB Banner and Joglo Village

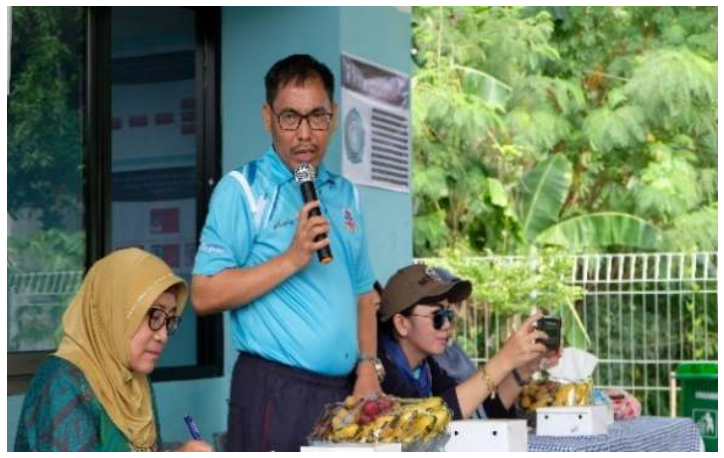

Figure 2. Message from the Joglo Village Head

In Figure 1, shows a banner that reads the collaboration of Mercu Buana University and Joglo Village, this is an initiative from Headman who wants cooperation between Joglo village and Mercu Buana University not only at this time but for the future. The theme of Community Service is "Composting Household Kitchen Waste Supporting Environmental Sanitation" because one of MBU campus culture is Environmental Conservation. Then in Figure 2, a speech from the Joglo village head Walman Debataraja, SKM, MSi, welcomed the cooperation in this community service and requested that its citizens be serious to follow it because this activity supports the Joglo village program which just won the first place in the nMBUer of most garbage banks in the village . 


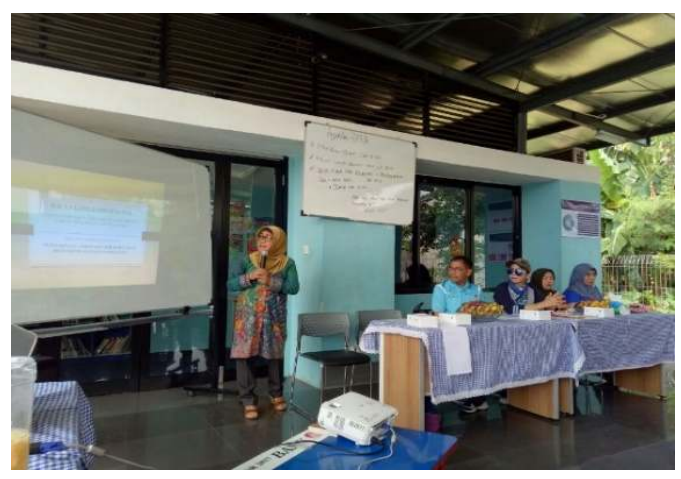

Figure 3. Explanation of the MBU Extension

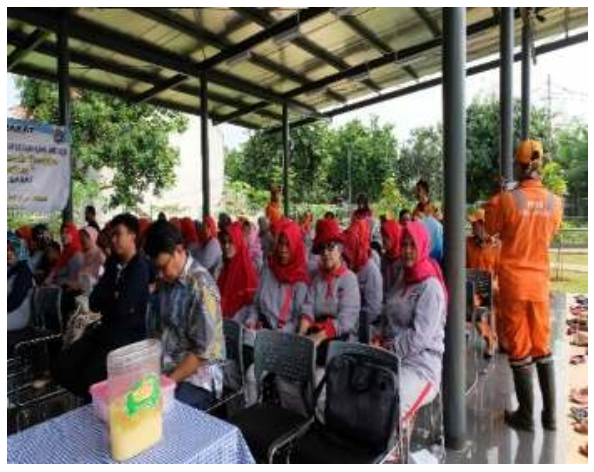

Figure 4. Training participants

In Figure 3, it is apparent that extension workers from Mercu Buana University explained the importance of making organic compost starting from kitchen waste by housewives whose results are hygienic and odorless and not dirty because the microorganisms are taken from yeast tape, cheap tempeh. Figure 4 shows the training participants consisting of PKK mothers, Youth organization and housewives were very attentive and serious in participating in counseling and training from the beginning to the completion of the training.

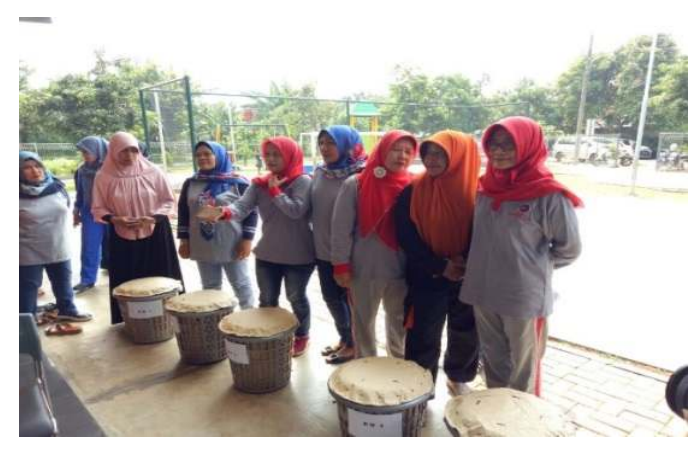

Figure 5: Representatives of each RW in Students Joglo village

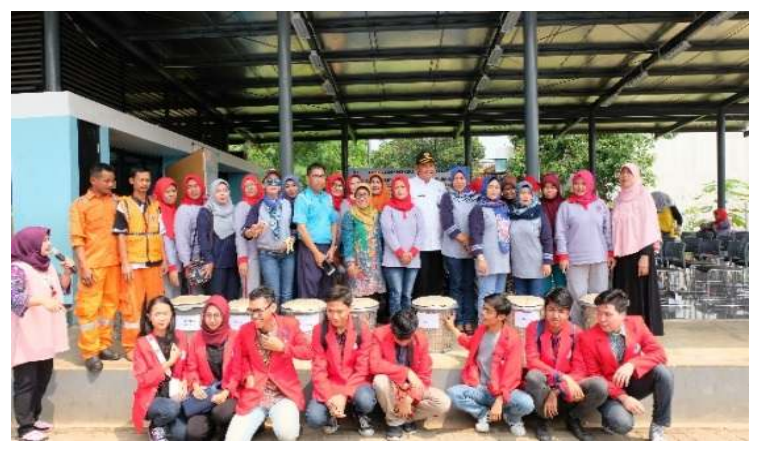

Figure 6. FEB-Management attended PPM in Joglo Village

Figure 5 is a picture of mothers from each Citizens Association (Indonesian known as RW) in Joglo village CA 001, 002, 003, 004, 006 and 008) representing their Citizens Association (Indonesian known as RW) in the next Takakura compost. Figure 6 shows that students of the Faculty of Economics and Business majoring in Management are actively involved in community service.

The training was conducted after the explanation of the material, followed by all participants consisting of PKK mothers, Youth organization, housewives, especially representatives from each Citizens Association (Indonesian known as RW), there were 6 Citizens Association (Indonesian known as RW) namely Citizens Association (Indonesian known as RW)01, 02, 03, 04, 06 and 08, plus representatives of the Joglo village and the lurah themselves. The participants were very enthusiastic about taking part in the training, as evidenced by interesting discussions and quality questions.

Evaluation I was done after one month from the beginning of composting, which is on Monday, June 4,2018 . The results of our evaluation turned out that one of the 8 composts failed, this was because during the composting process the compost basket was washed with rain water, so that the decomposing bacteria grew, which cause rotten compost not to smell good. Whereas the seven baskets were successful. as indicated by the smell of the compost, it was not rotten and even fragrant, and the compost was blackish brown and dry (Figure 7). 


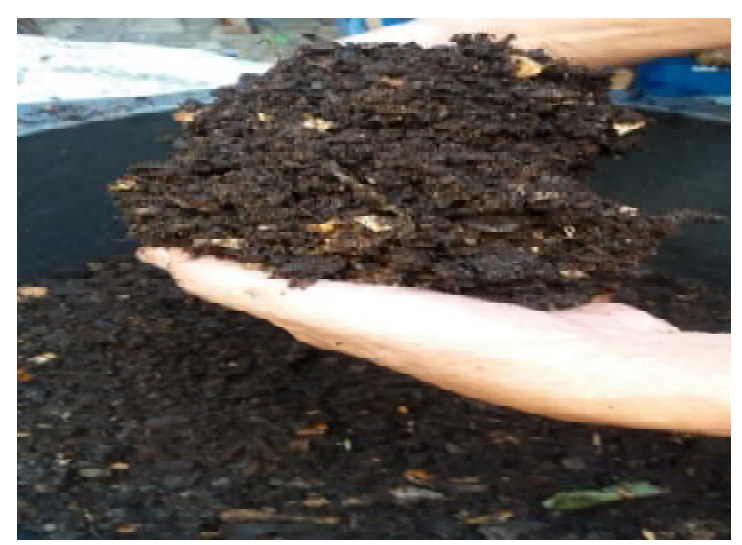

Figure 7. Composting Results

Evaluation I was done after one month from the beginning of composting, which is on Monday, June 4, 2018. The results of our evaluation turned out that one of the 8 composts failed, this was because during the composting process the compost basket was washed with rain water, so that the decomposing bacteria grew, which cause rotten compost not to smell good. Whereas the seven baskets were successful. as indicated by the smell of the compost, it was not rotten and even fragrant, and the compost was blackish brown and dry (Figure 7).

Evaluation II was carried out after two months from the start of composting, namely on Wednesday, July 4 2018. The results of our evaluation turned out that all (8) compost baskets were successful, this was because during the composting process housewives were diligent in disposing of their household waste. after cooking into the basket in a dry state does not contain water, so the microorganisms in the starter quickly multiply and remodel the organic ingredients become smaller and blackish brown, signifying the success of the composting process and not odor.

\section{Discussion}

The results of our monitoring for two months showed that PKK mothers and assisted mothers showed a great desire and willingness to learn and process their own waste after finishing cooking with the kitchen waste they produce every day. This is evidenced by a smooth discussion between the trainer and participants during the training. Also evidenced by the results of the first evaluation only one waste basket failed (12.5\%), while the successful one was 7 baskets $(87.5 \%)$. Then proceed with the results of the second evaluation, all of them (100\%) succeed.

The results of interviews of $10 \mathrm{PKK}$ mothers / assisted mothers representing participants who attended the training showed that 8 people $(80 \%)$ stated that they had not previously known Takakura composting which is practical and easy for housewives, in the presence of this training becomes know and interested in doing it alone at home, because it is very useful for household cleanliness. Some even want to develop themselves into compost for fertilizing crops from their household organic waste.

Whereas 2 mothers (20\%) had received training on composting but it was not completed due to confusion of finding a starter of microorganisms. But with this training the mothers became clearer from the start of the microorganism starter, the way to collect kitchen waste, how to put the garbage in the Takakura basket until the composting process was successful. The mother was satisfied and pleased with this training because her desire to process her own kitchen waste was fulfilled. With the results and discussion above, the output target plan can be achieved, this can be explained in Table 2 .

Scientific publications in journals are still in draft form. Besides that there is an increase in added value in this composting process, which is usually composting uses a starter in the form of liquid with an expensive price, but here in composting uses a starter of microorganisms that can be made by housewives. In this community service there is also an increase in the application of science and technology, because in the composting process is used mokroorganisme from tape, yeast that does not pollute the environment and does not damage environmental sanitation if fertilizer is made. 
Table 2. Achievement Target After PPM Activity Training

\begin{tabular}{|c|l|c|}
\hline No. & \multicolumn{1}{|c|}{ Type } & $\begin{array}{c}\text { Achievements } \\
\text { Indicator }\end{array}$ \\
\hline 1. & Scientific publication in ISSN journal / proceedings & draft \\
\hline 2. & Publications on the mass media & reached \\
\hline 3. & $\begin{array}{l}\text { Increased competitiveness (increasing quality, quantity and } \\
\text { added value) }\end{array}$ & $\begin{array}{l}\text { reached } \\
\text { community (mechanization, IT, management) }\end{array}$ \\
\hline 5. & $\begin{array}{l}\text { Improvement of community values (art, culture, tranquility, } \\
\text { education, health) }\end{array}$ & reached \\
\hline
\end{tabular}

So that environmental preservation is maintained, as well as living things that live around it. So composting using microorganism technology does not produce a bad smell, it even smells good. So that with this community service there is an improvement in the society's value system, in which the community becomes healthier because from now on housewives can process their household kitchen waste properly and cleanly. In his speech by the village head, Walman Debataraja, SKM, MSi gave direction and encouragement to the women of PKK, Youth organization and other assisted mothers so that the knowledge gained about household kitchen waste composting is actually applied in their respective households so as not to there is a buildup of garbage in our environment, so that our environment is clean from mosquitoes, rats, cockroaches so that our families become healthier all of them. This was conveyed by Headman because the composting delivered by the Mercu Buana University team supported Joglo's village program on composting organic waste, in which joglo village got the first prize about the largest nMBUer of garbage banks in the Village.

\section{CONCLUSION}

Community Service Program with the theme "Composting Household Kitchen Waste Supporting Environmental Sanitation": 1) Can increase the added value of mothers' skills in composting household kitchen waste with the Takakura Method, 2) Can improve the application of science and technology, by utilizing organic material microorganisms as decomposers, 3) Can improve the improvement of people's values, especially family health

\section{Suggestion}

1)Further training is needed on the use of composted organic waste in preserving the environment and its marketing, 2) It needs cooperation with private companies that have more organic waste such as restaurants, so that the processing of kitchen waste does not pollute the environment.

\section{REFERENCES}

Alex, S. (2012).Success in Processing Organic Waste into Organic Fertilizer. Yogyakarta:New Library Press.

Faizah. (2008). Community-Based Household Waste Management (Case Study in the City Yogyakarta). Semarang: Thesis of Diponegoro University

Hidayah, A.(2017). Takakura Home Method. Smart Solution Creating Makassar Ta 'No Rantasa. PENA Journal, 4 (2): 724 - 731

Nurullita, U and Budiyono. (2012). Duration of Household Waste Composting Based on Local Organism Micro Types (MOL) and Composting Techniques. http: // jurnal.unimus.ac.id: 236 $-245$ 
Rezagama, A and Samudro, G. (2015). Study of Takakura Optimization with the addition of husks and bran. Journal of Precipitation, 12 (2): 66 - 70

Setiawan, R and Arifendi, R.F. (2016). The use of Chabi (Charming Dustbin) and Basket Takakura as an Effort to Increase Environmental Concern for Primary School Children. Indonesian Journal of Biological Education, 2 (3): 215 - 221

Tim Move Indonesia. (2007). Let's Make Compost Takakura. Center for Environmental Education Life. (PPLH). Selolima, Trawas. Mojokerto. 